DOI: 10.46340/eppd.2021.8.2.10

\title{
Oleh Didenko
}

ORCID ID: https://orcid.org/0000-0002-2279-947X

National Academy of Internal Affairs, Kyiv, Ukraine

\section{CLASSIFICATION OF CONSTITUTIONAL AND LEGAL GUARANTEES OF THE RIGHT TO ELECT AND BE ELECTED TO PUBLIC AUTHORITIES}

\author{
Олег Діденко \\ Національна академія внутрішніх справ, м. Київ, Україна

\section{КЛАСИФІКАЦІЯ КОНСТИТУЦЙНО-ПРАВОВИХ ГАРАНТІЙ ПРАВА ОБИРАТИ ТА БУТИ ОБРАНИМ ДО ОРГАНІВ ПУБЛІЧНОЇ ВЛАДИ}

The purpose of the article is to raise awareness about the existing approaches to the classification of constitutional and legal guarantees of the right to elect and to be elected to public authorities, the disclosure of their individual species. The evident attention of the scientific community to the institution of suffrage, to the guarantees of human rights and freedoms of citizen, of course, certified the importance of constitutional and legal guarantees of the right to elect and to be elected to state authorities and to bodies of local self-government in Ukraine. Especially it became actual with the adoption of the Electoral Code of Ukraine in 2019 and the elections hold on its basis. Approaches to classification of guarantees, understanding and provision of proper effects are ambiguous, but it is a key to identifying these guarantees as those being established by constitutional and legal norms aimed at effective provision of active, passive and nomination law.

Without denying the established position about the classification of guarantees on political, economic, organizational and legal ones, it is appropriate to complement them with ideological guarantees, as well as to distinguish the features of generally recognized and domestic, special and procedural guarantees; guarantees of the subjects of the electoral process; the levels of implementation of such guarantees, etc. In particular, domestic guarantees are enshrined in the Constitution of Ukraine, the Electoral Code of Ukraine and other legal acts, while international guarantees are contained in relevant international documents. Their content contains the legal mechanisms for the implementation, protection and defense of the right to elect and to be elected, and the functional focus is to ensure active, passive and nominative rights of citizens. Such guarantees are part of a broader system of guarantees of citizens' voting rights. The further studying of the abovementioned questions can be promising, taking into account foreign experience, national interests, needs and opportunities of citizens, as well as modern information technologies, etc.

Keywords: constitutional and legal guarantees, the right to elect, the right to be elected, guarantees of human rights, species, Electoral code of Ukraine.

Постановка проблеми. За останні роки в Україні відбулось активне реформування національного законодавства у багатьох сферах суспільних відносин. Особливо це стосується політичної сфери життєдіяльності, виборчих відносин. Не дивлячись на тривалий пошук оптимальної моделі виборчої системи, з початку 90-х років XX століття, лише наприкінці 2019 р. прийнято кодифікований акт, а саме Виборчий кодекс України. Це зумовило потребу грунтовного теоретичного вивчення низки ключових категорій, відповідних концептуальних підходів і засад їх розуміння i трактування, насамперед, з метою належного правозастосування. До таких можна віднести і виборче право, конституційно-правові гарантії права обирати та бути обраним до органів державної влади та місцевого самоврядування в Україні. 
Аналіз останніх досліджень та публікацій. Неодноразово до проблематики гарантій прав людини, у тому числі виборчих прав, звертались у своїх наукових розвідках переважно вітчизняні сучасні вчені. Варто згадати праці учених конституціоналістів і муніципалістів, рідше представників науки адміністративного і кримінального права тощо. Так, відзначимо, внесок таких дослідників як Л. Гудзь, М. Гультай, В. Демиденко, Н. Камінська, В. Кампо, Ю. Ключковський, Р. Князевич, В. Кравченко, А. Магера, О. Марцеляк, В. Нестерович, І. Панкевич, В. Погорілко, М. Рябець, А. Селіванов, С. Серьогін, М. Смокович, О. Совгиря, М. Ставнійчук, Ю. Тодика, В. Федоренко, О. Фрицький, М. Цвік, В. Шаповал, Н.Шаптала та ін. Водночас, залишається чимало питань залишається предметом розгляду сучасної правової науки у даному контексті, що вимагають продовження наукових дискурсів.

Тому метою даної статmі є звернення уваги на існуючі підходи до класифікації конституційно-правових гарантій права обирати та бути обраним до органів публічної влади, розкриття особливостей їх окремих видів.

Виклад основного матеріалу. У наукових джерелах поширене використання категорій «юридичні гарантії», «правові гарантії» та «конституційно-правові гарантії» тощо. Слід зазначити, що у різних державах як на рівні законодавства, так і на рівні політико-правової доктрини неоднозначними $\epsilon$ підходи до їх регламентації та трактування. Спостерігається ситуація, коли іноді відсутні визначення цих понять у законодавстві або, навпаки, активно згадуються вони з належною інтерпретацією.

Звернення до юридичної енциклопедичної літератури демонструє розуміння гарантій прав і свобод людини та громадянина як сукупності умов, засобів і способів, які забезпечують здійснення в повному обсязі та всебічну охорону прав і свобод особи. Поняття «гарантії» (франц. garantie забезпечення, порука, запорука; умова) охоплює об'єктивні та суб'єктивні чинники, спрямовані на практичну реалізацію прав і свобод, усунення можливих перешкод їх повного або належного здійснення ${ }^{1}$ У словниках наведено ряд значень цього терміну: як забезпечення здійснення чогонебудь і як умова, яка забезпечує, підтверджує здійснення, виконання чого-небудь; гарантування як дія розглядається в якості синоніму захисту, забезпечення; як сукупність установлених процесуальних та інституційних засобів захисту прав і свобод людини та громадянина, меж і умов їх можливих обмежень ${ }^{2}$.

Узагальнення існуючих концептуальних підходів до розуміння конституційно-правових гарантій права обирати та бути обраним дозволяє їх визначити як упорядковану систему законодавчо регламентованих умов і правил, засобів і способів, що забезпечують повною мірою можливості громадян обирати та бути обраним до органів державної влади та місцевого самоврядування в Україні, організацію і проведення виборів відповідно до чинного законодавства, міжнародноправових стандартів у даній сфері ${ }^{3}$.

Т. Заворотченко підкреслює, що поняття гарантій відрізняється від конституційно-правових гарантій тим, що останні встановлюються Основним Законом держави та іншими законодавчими актами ${ }^{4}$. Л. Гудзь розглядає гарантії суб'єктивного виборчого права, перелічує систему соціально-

\footnotetext{
${ }^{1}$ Діденко, О. М. (2020). Концептуальні підходи до визначення конституційно-правових гарантій права обирати та бути обраним. Сучасні аспекти науки: колективна монографія. Київ; Братислава, 199-216; Шемшученко, Ю. С. (ред.) (2012). Великий енциклопедичний юридичний словник. Київ: Юридична думка, 1020. ${ }^{2}$ Наливайко, Л. Р., Беляєва, М. В. (2010). Тлумачний термінологічний словник з конституційного права. Запоріжжя, 304; Ожегов, С. И., Шведова, Н. Ю. (2006). Толковый словарь русского языка: 80000 слов и фразеологических выражений. Москва; Catanese, М. (2006). Florencia. Garantías constitucionales del procesopenal. Facultad de Derecho. Universidad de Buenos Aires <http://www.derecho.uba.ar/graduados/ponencias/catanese.pdf> (2020, березень, 10); Wilhelmi, M. A., Pisarello, G. (2008). Los derechos humanos y sus garantías: naciones básicas. In: Pérez, J. B., Sánchez, V. M. (comps.) Los derechos humanos en el siglo XXI. Continuidad y cambios. Barcelona: Huygens Editorial, 31.

${ }^{3}$ Гудзь, Л. В. (2006). Гарантії виборчих прав громадян України і досвід їх реалізації в зарубіжних країнах. Вісник Харківського національного університету внутрішніх справ, 33, 50-58; Діденко, О. М. (2019). Еволюція розвитку виборчого законодавства України. Науковий вісник Луганського державного університету внутрішніх справ ім. Е. О. Дідоренко, 4, 35-45; Діденко, О. М. (2020). Концептуальні підходи до визначення конституційно-правових гарантій права обирати та бути обраним. Сучасні аспекти науки: колективна монографія. Київ; Братислава, 199-216.

4 Заворотченко, Т. М. (2002). Конституційно-правові гарантії прав і свобод людини і громадянина в Україні: дисертація на здобуття наукового ступеня кандидата юридичних наук. Київ: НАН України. Інститут держави і права ім. В.М.Корецького, 220.
} 
економічних, політичних, юридичних, організаційних передумов, засобів і способів, які створюють рівні можливості та оптимальні умови для безперешкодного здійснення громадянином своїх виборчих прав, свобод та інтересів. Відзначено, що юридичні гарантії охоплюють усі правові засоби, які забезпечують здійснення й охорону виборчих прав громадян. Їх можна розділити на дві групи:

a) гарантії реалізації (використання) виборчих прав - юридичні засоби, які забезпечують правомірну реалізацію прав і свобод;

б) гарантії захисту виборчих прав - юридичні засоби, які їх охороняють ${ }^{1}$.

О.М. Стаднік виділяє об’єктивні гарантії реалізації виборчих прав та визначає їх як закріплені в нормах Конституції України основоположні норми-гарантії, норми-принципи, які певною мірою гарантують основним суб'єктам виборчого процесу реалізацію своїх виборчих прав - право обирати та бути обраним до органів державної влади чи до органів місцевого самоврядування ${ }^{2}$.

У виданні «Вибори і референдуми в Україні: проблеми теорії і практики» за ред. М. М. Рябця до нормативно-правових гарантій безпосередньої демократії відносять сукупність відповідно прийнятих норм права, які визначають загальні принципи функціонування інститутів прямого народовладдя і коло суб'єктів здійснення безпосередньої демократії та цілі, яких вона має досягнути ${ }^{3}$.

У свою чергу, гарантії виборчих прав розглядають крізь призму видів виборів. Наприклад, Р. Князевич вивчає гарантії виборів Президента України, класифікуючи на 1) національні (загальносоціальні, організаційно-правові та нормативно-правові), 2) міжнародно-правові гарантії виборів Президента України. При цьому до загально-соціальних гарантій виборів Президента України згаданий автор відносить політичні, економічні, ідеологічні тощо

Гарантії права обирати та бути обраним часто характеризуються через встановлення ознак i змісту їх окремих складових чи видів забезпечення. В. Мостовщіков, виділяючи судові і позасудові гарантії виборчих прав, поділяє останні на

1) загальні, що реалізуються в рамках захисту конституційних прав і свобод людини i громадянина (заборона на застосування будь-яких нормативних правових актів, які зачіпають права, свободи і обов'язки людини і громадянина, якщо вони не опубліковані офіційно для загального відома; забезпечення державного захисту прав і свобод людини і громадянина; надання кожній людині права на самозахист; заборона на видання законів, які скасовують або применшують права i свободи людини і громадянина, встановлення можливості обмеження прав і свобод людини i громадянина лише в суворо визначених в Конституції випадках);

2) спеціальні, що реалізуються в рамках захисту виборчих прав (обов'язок виборчих комісій розглядати звернення про порушення законів, проводити перевірки за цими зверненнями, ініціювати подання про проведення перевірок та припиненні порушень виборчого законодавства, право комісії звертатися до органів судової влади з питань ії компетенції, а також розглядати скарги і заяви на рішення нижчих комісій) ${ }^{5}$.

Загалом найбільш поширена наукова позиція, за якою розрізняють чотири види гарантій: економічні, політичні, організаційні та юридичні. Спостерігається вузький підхід до класифікації гарантій виборчих прав, який передбачає віднесення наявних у законодавстві принципів, засобів чи механізмів до конкретної групи гарантій (політичні: порядок висунення кандидатів, правила голосування, принцип рівності суб'єктів виборчого права та ін.; організаційні: діяльність уповноважених суб'єктів виборчого права, принципи діяльності виборчих комісій, автоматизованої системи виборів тощо; економічні: умови фінансування виборів, відповідні фінансові заборони тощо).

Серед вітчизняних учених домінує більш загальний підхід до диференціації електоральних гарантій, за яким до тісї чи іншої групи гарантій відносяться загальні явища суспільного життя, без прямого зв'язку з нормами виборчого права. Багато дослідників, розглядаючи гарантії реалізації

\footnotetext{
${ }^{1}$ Гудзь, Л. В. (2006). Гарантії виборчих прав громадян України і досвід їх реалізації в зарубіжних країнах. Вісник Харківського націоного університету внутрішніх справ, 33, 51-52.

${ }^{2}$ Стаднік, О. М. (2010). Загальносоціальні та нормативно-правові гарантії реалізації виборчих прав. Часопис Киїського університету права, 3, 77-81.

${ }^{3}$ Рябець, М. М. та ін. (ред.) (2001). Вибори і референдуми в Украӥні: проблеми теорії і практики. Київ: Центральна виборча комісія, 336.

${ }^{4}$ Князевич, Р. П. (2002). Конституційно-правові засади виборів Президента України: проблеми теорії і практики: автореферат дисертації на здобуття наукового ступеня кандидата юридичних наук. Одеса: Одеська Національна Юридична Академія, 18.

${ }^{5}$ Веденеев, Ю. А., Мостовщиков, В. Д. (2003). Введение в избирательное право. Москва: РЦОИТ, 208.
} 
виборчих прав громадян звертають увагу, що політичні гарантії - це зорієнтована політика держави, iii направленість на створення стійких політичних структур, які виключають дестабілізацію у суспільстві. Економічні гарантії, продовжує автор, передбачають відповідну матеріальну основу, яка покликана забезпечувати вільне використання прав. Одним із основних завдань законодавства $€$ створення рівних політичних і економічних можливостей громадян при реалізації пасивного i активного виборчого права ${ }^{1}$.

Д. Реут визначає інформаційні гарантії як гарантії виборчих прав, що виражаються в обов'язковому доведенні до відома виборців інформації про вибори та класифікує їх: за стадіями виборчого процесу на гарантії, що застосовуються в період виборчої кампанії та гарантії, що застосовуються поза періодом виборчої кампанії; за функціями на гарантії, спрямовані на забезпечення можливості участі виборців у виборах, гарантії, спрямовані на забезпечення усвідомленості волевиявлення, свободи і відповідальності вибору, гарантії, спрямовані на забезпечення громадського контролю за підготовкою і проведенням виборів ${ }^{2}$.

Наведені наукові підходи свідчать про певну ситуативність досліджень у сфері гарантування виборчих прав, зокрема дана тематика досліджується або дуже широко (гарантування виборів, гарантії безпосередньої демократії), або вузько (нормативний аспект, об'єктивне чи суб'єктивне розуміння, окремий вид гарантій чи виборів тощо).

У Виборчому кодексі Туркменістану 2013 р. розрізняються законодавчі та правові гарантіі. Законодавчі гарантії пов'язані з регулюванням проведення виборів в державі та визначенням правового статусу виборців, кандидатів, виборчих комісій та інших учасників виборчого процесу та референдуму. Водночас під правовими гарантіями розуміються умови забезпечення загальних прав людини та громадянина під час виборів чи референдуму, встановлених нормами міжнародного та національного права. Зокрема, це право на вільне волевиявлення, особисту недоторканність, право на охорону виборчих прав та їх судовий захист тощо. Економічні гарантії полягають у забезпеченні державою рівних фінансових можливостей для участі громадян у виборах шляхом організації та проведення виборів за рахунок коштів Державного бюджету. Організаційні гарантії включають порядки та процедури щодо утворення виборчих округів та дільниць, формуванню виборчих комісій, складанню списків виборців, реєстрації кандидатів, організації агітації, проведення виборів, підрахунку голосів та оголошення результатів голосування.

Відповідно до ст. 15 Виборчого кодексу Туркменістану інформаційні гарантії передбачають здійснення виборчого процесу та референдуму на засадах гласності та широкої інформованості громадян ${ }^{3}$.

Останнє положення знаходить відповідне відтворення і у вітчизняних наукових роботах. Так, О.Д. Лізунова розглядає категорію «інформаційне забезпечення виборів» та відносить іiі певною мірою до складу системи гарантій виборчих прав громадян ${ }^{4} .3$ розвитком інформаційних технологій і впровадження їх у виборчий процес актуалізуються проблеми визначення, реалізації інформаційних гарантій виборчих прав громадян.

Особливістю конституційно-правових гарантій права обирати та бути обраним до органів публічної влади в Україні $\epsilon$ їх до певної міри дуалістична правова природа, тобто їх зміст визначається як міжнародними документами, так і національним законодавством. Загальновизнані гарантії виборчих прав встановлені у Загальній декларації прав людини, затвердженій Генеральною Асамблеєю ООН 1948 р., Міжнародному пакті про громадянські та політичні права 1966 р., Конвенції про захист прав людини і основоположних свобод 1950 p. та іiі Протоколі №1. Спеціальними міжнародними актами, де конкретизуються загальновизнані права усфері виборчого права, $є$

\footnotetext{
${ }^{1}$ Гудзь, Л. В. (2005). Гарантії реалізації виборчих прав громадян: проблеми і перспективи. Вісник Харківського національного університету внутрішніх справ, 31, 368-375.

2 Реут, Д. А. (2015). Информирование избирателей как гарантия реализации активного избирательного права граждан в Российской Федерации: дисертация на соискание научной степени кандидата юридических наук. Москва: Академия Генеральной прокуратуры РФ, 225.

${ }^{3}$ Избирательный кодекс Туркменистана, 2013 (с изменениями и дополнениями по состоянию на 09.06.2020) (Меджлис Туркменистана). Юрист <https://online.zakon.kz/document/?doc_id=31386493 \#pos=6;-106> (2020, липень, 09).

4 Лізунова, О. Д. (2019). Конституційно-правові основи інформаційного забезпечення виборів в Україні: дисертація на здобуття наукового ступеня кандидата юридичних наук. Київ: Національна Академія Наук України Інститут Держави I Права ім. В. М. Корецького, 237.
} 
Декларація про критерії вільних і справедливих виборів від 1994 р., Загальна декларація про демократію від 1997 р., Конвенція про стандарти демократичних виборів, виборчих прав і свобод у державах-учасницях СНД 2002 р, Кодекс належної практики у виборчих справах від 2002 р., Резолюція ПАРЕ «Про ліквідацію обмежень на право голосу» від 2005 р. тощо.

Ними встановлено гарантії права участі людини у державних справах своєї країни, у т.ч. і через реалізацію права на рівний доступ до державної служби; загального, рівного, прямого виборчого права при таємному голосуванні; мінімальні вимоги демократичності, справедливості та транспарентності виборів, виконання яких є підставою для визнання виборів з боку іноземних держав. Зокрема, зазначена Конвенція 2002 р. підтверджує необхідність законодавчого гарантування права обирати та бути обраним, тобто конституційного закріплення цього права і визначення особливостей його реалізації у законах держави. Деталізовано організаційну гарантію пасивного виборчого права в частині паритетного підходу до формування виборчих округів.

Однією з матеріальних гарантій права бути обраним є фінансування виборчої кампанії кандидата. Конвенція підтверджує загальновизнані економічні заходи виборчого процесу: фінансування виборів державою; заборона фінансування виборчих кампаній кандидатів з іноземних джерел; регулювання формування виборчих фондів кандидатів; сувора звітність щодо руху коштів виборчих фондів ${ }^{1}$. Однак тут не згадується про інститут застави для кандидатів та відсутні застереження щодо майнових фільтрів при реєстрації кандидатів.

У Декларації про критерії вільних і справедливих виборів від 1994 р. конкретизується низка принципів виборчого права, вона є обов'язковою для країн, які до неї приєдналися. У контексті цього дослідження інтерес становлять гарантії особистої безпеки кандидатів, вимоги невтручання держави у вибори, недопустимості підкупу виборців та принципи механізму проведення виборів. Так, у п.п. 5, 8 згаданої Декларації встановлено, що право кандидатів на безпеку їх життя і власності повинно бути визнано і захищено. Держави повинні вжити необхідних заходів, щоб партії, кандидати та їх прихильники користувалися рівною безпекою, а державні органи виконували необхідні кроки для запобігання випадкам насильства в ході виборів ${ }^{2}$. Прикметно, що на сьогодні у Кримінальному кодексі України 2001 р. не закріплено спеціальних складів злочинів проти життя, здоров'я та власності як кандидатів, так і довірених осіб, спостерігачів і посадових осіб політичних партій.

Еталонним документом Ради Європи у галузі виборчого права є Кодекс належної практики у виборчих справах, ухвалений Венеціанською Комісією 2002 р. В його основу закладено керівні принципи щодо виборів, які стали наслідком узагальнення та стандартизації досвіду європейських виборчих систем. Так, загальноєвропейськими виборчими принципами визнаються загальність, рівність, вільність, таємність і безпосередність виборчого права ${ }^{3}$. У вказаному Кодексі деталізуються їх зміст та особливості реалізації. За своєю суттю зазначені принципи мають гарантійну природу та в контексті нашого дослідження можуть розглядатися як гарантії права обирати та бути обраним.

Реалізацію права обирати та бути обраним розробники Кодексу корелюють з такими умовами: додержання основних прав людини, конституційно-правове регулювання виборчого процесу, стабільність виборчого законодавства, наявність відповідального органу за проведення виборів, безсторонність цього органу, ефективний моніторинг виборів, дієві механізми захисту виборчих прав.

Особливу увагу слід звернути на положення Кодексу про те, що основні елементи виборчого права, зокрема власне виборчу систему, склад виборчих комісій і визначення між виборчих округів не можна переглядати менш, як за рік до проведення виборів або ж їх треба закріпити в конституції або в документі, що має більше високий статус, ніж звичайний закон; виборче законодавство має бути захищеним від партійно-політичних маніпуляцій ${ }^{4}$. Заборона частої зміни виборчого законодавства, особливо перед виборами, є важливою гарантією його стабільності, але передбачене Кодексом

\footnotetext{
${ }^{1}$ Конвенція Про стандарти демократичних виборів, виборчих прав і свобод у державах-учасничях СНД, 2002 (Верховна Рада України). Офіиійний сайт Верховної Ради Украйни

<https://zakon.rada.gov.ua/laws/show/997_622\#Text> (2020, December, 23).

2 Деклараиия о критериях свободных и справедливых виборов, 1994 (Совет Межпарламентского Союза). Демократия.pу <https://www.democracy.ru/library/laws/international/el_declaration1994.html> (2020, June, 05).

${ }^{3}$ Ключковський, Ю. (ред.) (2009). Свропейський демократичний доробок у галузі виборчого права. Матеріали Венеиіанської Комісії, Парламентської Асамблеї, Комітету Міністрів, Конгресу місиевих і регіональних влад Ради Європи. Київ, 500.

${ }^{4}$ Там само.
} 
застереження про можливість обійти цю заборону, через внесення відповідних змін до законів вищого рівня, може повністю нівелювати цю гарантію. Зокрема, для країн з демократією, що розвивається і неусталеною повною законодавчою процедурою це застереження може бути використано для маніпуляцій з виборчим законодавством 3 боку провладної більшості. У цьому контексті дієвим видається такий спосіб уникнути маніпулювання - зазначити в конституції, що в разі внесення змін до закону про вибори на наступних виборах ще буде застосовано колишню систему, принаймні якщо ці вибори відбудуться протягом наступного року, а нова система набуде чинності вже після цього. Видається, що для деяких країн, в яких ще відсутня демократична виборча традиція, такий спосіб зміни виборчого законодавства має бути визнаний обов'язковим.

Конституційне закріплення мають і гарантії загального, рівного, прямого, вільного та таємного виборчого права, що встановлені у ст.71 Розділу III «Вибори. Референдум» Конституції України ${ }^{1}$. Особливості реалізації гарантій активного та пасивного виборчого права встановлені у Виборчому кодексі України. Аналіз його структури і змісту дозволяє виділити специфічні риси використаного законодавцем підходу до гарантування виборчих прав громадян. Так, його розробники наділили принципи гарантійною природою та через них закріпили загальновизнані гарантії виборчого права.

Водночас у цьому Кодексі окремо регулюються питання інформаційного, матеріальнотехнічного і фінансового забезпечення виборів. 3 огляду на етимологію поняття та зміст категорії «гарантії», очевидно законодавець окремо виділяє інформаційні, матеріально-технічні та фінансові гарантії виборів. Через те, що у законодавстві прямо визначена сфера їх дії (забезпечення виборів, їх підготовки та проведення), то можна говорити про процесуальну природу цих гарантій. При цьому у Кодексі використовується, але не розкривається зміст, поняття гарантій. Зокрема, законодавчо закріплені гарантії діяльності кандидатів, політичних партій, офіційних спостерігачів та інших суб'єктів виборчого процесу на виборах. Однак розгляд відповідних статей Кодексу щодо зазначених «гарантій діяльності» свідчить про їх змішану правову природу, оскільки вони стосуються скоріше гарантій трудових прав кандидатів (право на неоплачувану відпустку під час виборів, заборона звільнення або переведення кандидата без його згоди) та додаткових гарантій представництва кандидатів та інших суб'єктів виборчого процесу під час виборів (через уповноваженого представника, довірених осіб, офіційних спостерігачів).

За своєю суттю зазначені гарантії швидше стосуються окремих аспектів та умов участі кандидатів та інших суб'єктів виборчого процесу у виборах, а не їх діяльності. Окремо звернемо увагу на визначені законодавцем типи виборів та закладення їх типології в основу класифікації різновидів гарантій виборчих прав та виборчого процесу. Так, Виборчий кодекс України виходячи із класифікації загальнодержавних виборів та місцевих виборів, окремо регулює спеціальні організаційні, фінансові та інформаційні гарантії підготовки та проведення різних типів виборів.

На підставі вищевикладеного, закладеного у кодексі змішаного підходу розуміння гарантування виборчих прав, можна виділити систему гарантій права обирати та бути обраним, що включає:

загальновизнані гарантії, представлені у Кодексі у виді принципів виборчого права; інформаційні, матеріально-технічні та фінансові гарантії підготовки та проведення різних видів виборів (закріплені у Кодексі через категорію «забезпечення»), які $\epsilon$

спеціальними (окремо визначені стосовно для кожного виду виборів),

процесуальними (поширюються на підготовку та проведення виборів) гарантіями;

гарантії діяльності суб'єктів виборчого процесу (визначені через поняття «гарантії»), які включать гарантію трудових прав кандидатів та декілька гарантій представництва суб'єктів у виборах, вони стосуються більше участі суб'єктів у виборчому процесі.

Взагалі законодавець розглядає гарантії у сфері виборчого права вузько, обмежуючи їх зміст двома різновидами гарантій участі суб'єктів у виборчому процесі (питання представництва і трудових прав). Такий підхід дещо дисонує з такими поняттями, які використовуються у Кодексі, але не уточнюються, як: «гарантії права громадян на участь у виборах», яке міститься у преамбулі Кодексу та поняття «гарантії реалізації виборчих прав громадян», що використовується для визначення основної засади виборчого процесу (п.1 ч. 1 ст. 21 Виборчого кодексу України). ${ }^{2}$

\footnotetext{
${ }^{1}$ Конституиія Украӥни, 1996 (Верховна Рада України). Відомості Верховної Ради України, 30, 141.

${ }^{2}$ Виборчий кодекс Украйни, 2019 (Верховна Рада України). Офіиійний сайт Верховної Ради України <https://zakon.rada.gov.ua/laws/main/396-IX> (2020, December, 23).
} 
Запропоновану систему гарантій виборчих прав громадян, встановлену на підставі аналізу Виборчого кодексу України, можна розглядати на трьох рівнях, залежно від їх обсягу, а саме:

1) на рівні загальновизнаних гарантій виборчих прав;

2) на рівні процесуальних гарантій виборчого процесу;

3) на рівні окремих видів гарантій участі суб'єктів у виборах (виділення цього рівня зумовлено прямим закріпленням саме цих гарантій у законодавстві).

Обмежений обсяг не дозволяє детально розглянути гарантії права обирати та бути обраним до органів державної влади та органів місцевого самоврядування в Україні на кожному із зазначених рівнів. Перспективними видаються ряд напрямів подальших наукових розвідок, зокрема, стосовно визначення ролі і значення юридичної відповідальності у системі гарантій права обирати та бути обраним до органів публічної влади, а також співвідношення і взаємозв'язку з гарантіями інших прав громадян у виборчому процесі.

Висновки. Модернізація національного законодавства України та досвід проведення виборів у нашій державі демонструє низку позитивних тенденцій. 3 прийняттям Виборчого кодексу 2019 р. i проведенням виборів на його основі засвідчена важливість конституційно-правових гарантій права обирати та бути обраним до органів влади в Україні. Неоднозначними є підходи до їх класифікації, розуміння і забезпеченням дієвості. Ключовим $є$ визначення власне цих гарантій як встановлених конституційно-правовими нормами правових механізмів, що спрямовані на ефективне забезпечення активного, пасивного та номінаційного права.

Не заперечуючи усталеного підходу до класифікації гарантій на політичні, економічні, організаційні та юридичні, доречним є їх доповнення ідеологічними, виокремлення особливостей загальновизнаних і внутрішньодержавних, спеціальних і процесуальних гарантій, гарантій діяльності суб'єктів виборчого процесу, рівні реалізацій таких гарантій і т.д. Зокрема, внутрішньодержавні гарантії закріплені в Конституції України, Виборчому кодексі України, інших нормативно-правових актах, а міжнародно-правові містяться у відповідних міжнародних документах. Їх зміст становлять правові механізми реалізації, охорони та захисту права обирати та бути обраним, а функціональна спрямованість полягає у забезпеченні активного, пасивного та номінаційного права громадян. Такі гарантії входять до складу більш широкої системи гарантій виборчих прав громадян.

Перспективним є подальше вивчення конституційно-правових гарантій права обирати та бути обраним до органів публічної влади, з урахуванням зарубіжного досвіду, національних інтересів, потреб і можливостей громадян, а також сучасних інформаційних технологій тощо.

\section{References:}

1. Catanese, M. (2006). Florencia. Garantías constitucionales del procesopenal [Florence Constitutional guarantees of the criminal process]. Facultad de Derecho. Universidad de Buenos Aires [Law School. Buenos Aires' University] <http://www.derecho.uba.ar/graduados/ponencias/catanese.pdf> (2020, December, 23). [in Spanish].

2. Deklaratsyia o kryteryiakh svobodnykh y spravedlyvykh vyborov, 1994 (Sovet Mezhparlamentskogo Soyuza) [Declaration at the criteria of freedom and just excretions, 1994 (Interparliamentary Union Council)]. Democracy.Ru <www.democracy.ru/library/Laws/International/El-Declaration1994/HTML> (2020, December, 23). [in Ukrainian].

3. Didenko, O. M. (2019). Evoliutsiia rozvytku vyborchoho zakonodavstva Ukrainy. [Evolution of the development of the electoral legislation of Ukraine]. Scientific Bulletin of the Lugansk State University of Internal Affairs them. E.O. Didorenk - Naukovyi visnyk Luhanskoho derzhavnoho universytetu vnutrishnikh sprav im. E. O. Didorenko, 4, 35-45. [in Ukrainian].

4. Didenko, O. M. (2020). Kontseptualni pidkhody do vyznachennia konstytutsiino-pravovykh harantii prava obyraty ta buty obranym [Conceptual approaches to the definition of constitutional and legal guarantees of the right to choose and be elected]. In: Romanenko, S. O., Zhukova, I. V. (ed.) Suchasni aspekty nauky [Modern aspects of science]. Kyiv; Bratyslava, 199-216. [in Ukrainian].

5. Ferrajoli, L. (2001). Derechos fundamentales en Cabo, Antonio de y Pisarello, Gerardo (coords.) [Fundamental rights in Cabo, Antonio de and Pisarello, Gerardo]. Los fundamentos de los derechos fundamentales [The foundations of fundamental rights]. Madrid: Trotta. [in Spanish].

6. Horun, O. V., Kaminska, N. V., Fatkhutdinova, O. V. (2011). Teoriia derzhavy ta prava [Theory of state and law]. Kyiv: KNT. [in Ukrainian].

7. Hudz, L. V. (2005). Harantii realizatsii vyborchykh prav hromadian: problemy i perspektyvy [Guarantees of implementation of electoral rights of citizens: problems and prospects.] Visnyk Kharkivskoho natsionalnoho universytetu vnutrishnikh sprav [Bulletin of the Kharkiv National University of Internal Affairs], 31, 368-375. [in Ukrainian].

8. Hudz, L. V. (2006). Harantii vyborchykh prav hromadian Ukrainy i dosvid yikh realizatsii v zarubizhnykh krainakh. [Guarantees of electoral rights of Ukrainian citizens and experience in foreign countries.] Visnyk Kharkivskoho 
natsionalnoho universytetu vnutrishnikh sprav - Bulletin of the Kharkiv National University of Internal Affairs, 33, 50-58. [in Ukrainian].

9. Kaminska, N. V. (2014). Jevropejsjka systema miscevogho i reghionaljnogho samovrjaduvannja ta Ukrajina [European system of local and regional self-government and Ukraine]. Kyiv: KNT. [in Ukrainian].

10. Klyuchkovskyy, Y. B. (2018). Pryntsypy vyborchoho prava: doktrynalne rozuminnya, stan ta perspektyvy zakonodavchoyi realizatsiyi v Ukrayini [Principles of suffrage: doctrinal understanding, status and prospects of legislative implementation in Ukraine]. Kyiv: Vaite. [in Ukrainian].

11. Knyazevych, R. P. (2002). Konstytutsiyno-pravovi zasady vyboriv Prezydenta Ukrayiny: problemy teoriyi i praktyky [Constitutional and legal principles of the election of the President of Ukraine: problems of theory and practice]: avtoreferat dysertatsiyi na zdobuttya naukovoho stupenya kandydata yurydychnykh nauk [dissertation abstract for the degree of Candidate of Law]. Odessa: Odessa National Law Academy. [in Ukrainian].

12. Konstytutsiia Ukrainy, 1996 (Verkhovna Rada Ukrayny). [Constitution of Ukraine, 1996 (Verkhovna Rada of Ukraine)]. Ofitsiynyy sayt Verkhovnoyi Rady Ukrayiny [The official website of the Verkhovna Rada of Ukraine]. <https://zakon.rada.gov.ua/laws/show/254\%D0\%BA/96-\%D0\%B2\%D1\%80/ed20200101\#Text> (2020, December, 23). [in Ukrainian].

13. Kryminalnyi kodeks, 2001 (Verkhovna Rada Ukrainy) [Criminal Code, 2001 (Verkhovna Rada of Ukraine)]. Ofitsiynyy sayt Verkhovnoyi Rady Ukrayiny [The official website of the Verkhovna Rada of Ukraine]. <https://zakon.rada.gov.ua/laws/show/2341-14\#Text> (2020, December, 23). [in Ukrainian].

14. Diario Oficial de la Federación (2020) [Official Gazette of the Federation (2020)]. Ley General de Instituciones y Procedimientos Electorales [General Law of Electoral Institutions and Procedures] <https://dof.gob.mx/nota_detalle.php?codigo=5591565\&fecha=13/04/2020> (2020, December, 23). [in Spainish].

15. Lizunova, O. D. (2019). Konstytutsiyno-pravovi osnovy informatsiynoho zabezpechennya vyboriv v Ukrayini [Constitutional and legal bases of information support of elections in Ukraine]: dysertatsiya na zdobuttya naukovoho stupenya kandydata yurydychnykh nauk [the dissertation on competition of a scientific degree of the candidate of legal sciences]. Kyiv: National Academy of Sciences of Ukraine Institute of State and Law name after V. M. Koretsky. [in Ukrainian].

16. Nalyvaiko, L. R., Beliaieva, M. V. (2010). Tlumachnyi terminolohichnyi slovnyk z konstytutsiinoho prava [The interpretation terminology dictionary from constitutional law]. Zaporizhya. [in Ukrainian].

17. Nesterovych, V. F. (2020). Vyborcha kampaniya: Slovnyk slenhovykh terminiv ta vyraziv [Election Campaign: Dictionary of slang terms and expressions]. Kyiv: Lira-K. [in Ukrainian].

18. Ozhehov, S. Y., Shvedova, N. Iu. (2006). Tolkovyi slovar russkoho yazyka: 80000 slov y frazeolohycheskykh vyrazhenyi [80000 Sloves and phraseologically crazy]. Moscow: A TEMP. [in Russian].

19. Konventsiia Pro standarty demokratychnykh vyboriv, vyborchykh prav i svobod u derzhavakh-uchasnytsiakh SND, 2002 (Verkhovna Rada Ukrayny). [About the standards of democratic elections, electoral rights and freedoms in the CIS member states. Convention, 2002 (Verkhovna Rada of Ukraine)]. Ofitsiynyy sayt Verkhovnoyi Rady Ukrayiny [The official website of the Verkhovna Rada of Ukraine]. <https://zakon.rada.gov.ua/laws/show/997_622\#Text> (2020, December, 23). [in Ukrainian].

20. Reut, D. A. (2015). Informirovaniye izbirateley kak garantiya realizatsii aktivnogo izbiratelnogo prava grazhdan v Rossiyskoy Federatsii [Informing voters as a guarantee of the implementation of the active suffrage of citizens in the Russian Federation]: disertatsiya na soiskaniye nauchnoy stepeni kandidata yuridicheskikh nauk [dissertation for the degree of candidate of legal sciences]. Moscow: Academy of the General Prosecutor's Office of the Russian Federation. [in Russian].

21. Skakun, O. F. (2006). Teoriia derzhavy i prava [Theory of state and law]. Kharkiv: Konsum. [in Ukrainian].

22. Stadnik, O. M. (2010). Zahalnosotsialni ta normatyvno-pravovi harantii realizatsii vyborchykh prav [All-social and regulatory guarantees of salutive rights]. Chasopys Kyivskoho universytetu prava [The magazine of the University of Law], 3, 77-81. [in Ukrainian].

23. Vedeneev, Yu. A., Mostovshchykov, V. D. (2003). Vvedenye v yzbyratelnoe pravo [Informing in removing law]. Moscow: RTsOYT. [in Russian].

24. Shemshuchenko, Yu. S. (ed.) (2012). Velykyi entsyklopedychnyi yurydychnyi slovnyk [Great Encyclopedic Legal Dictionary]. Kyiv: Yurydychna dumka. [in Ukrainian].

25. Vyborchyy kodeks Ukrayiny, 2019 (Verkhovna Rada Ukrayiny) [Electoral Code of Ukraine, 2019 (Verkhovna Rada of Ukraine)]. Ofitsiynyy sayt Verkhovnoyi Rady Ukrayiny [The official website of the Verkhovna Rada of Ukraine]. <https://zakon.rada.gov.ua/laws/main/396-IX> (2020, December, 23). [in Ukrainian].

26. Riabets, M. M. and others (ed.) (2001). Vybory i referendumy v Ukraini: problemy teorii i praktyky [Elections and referendums in Ukraine: problems of theory and practice]. Kyiv: Tsentralna vyborcha komisiia. [in Ukrainian].

27. Wilhelmi, M. A., Pisarello, G. (2008). Los derechos humanos y sus garantías: naciones básicas [Human rights and their guarantees: basic nations]. In: Pérez, J. B., Sánchez, V. M. (comps.) Los derechos humanos en el siglo XXI. Continuidad y cambios [Human rights in the 21 st century. Continuity and changes]. Barcelona: Huygens Editorial. [in Spanish].

28. Zakon Ukrayiny Pro Tsentralnu vyborchu komisiyu, 2004 (Verkhovna Rada Ukrayiny) [Law of Ukraine On the Central Election Commission (Verkhovna Rada of Ukraine)]. Vidomosti Verkhovnoi Rady Ukrainy [Bulletin of the Verkhovna Rada of Ukraine], 36, 448. (2020, December, 23). [in Ukrainian]. 
29. Zakon Ukrayiny Pro Derzhavnyy reyestr vybortsiv, 2007 (Verkhovna Rada Ukrayiny) [Law of Ukraine On the State Register of Voters (Verkhovna Rada of Ukraine)]. Vidomosti Verkhovnoi Rady Ukrainy [Bulletin of the Verkhovna Rada of Ukraine], 20, 282. (2020, December, 23). [in Ukrainian].

30. Zavorotchenko, T. M. (2002). Konstytutsiyno-pravovi harantiyi prav i svobod lyudyny i hromadyanyna v Ukrayini [Constitutional and legal guarantees of human and civil rights and freedoms in Ukraine]: dysertatsiya na zdobuttya naukovoho stupenya kandydata yurydychnykh nauk [dissertation for the degree of Candidate of Law]. Kyiv:

National Academy of Sciences of Ukraine. Institute of State and Law named after V. M. Koretsky. [in Ukrainian].

31. Klyuchkovsky, Yu. (ed.) (2009). Yevropeysky demokratychny dorobok u haluzi vyborchoho prava [European democratic achievements in the field of suffrage]. Materialy Venetsianskoyi Komisiyi, Parlamentskoyi Asambleyi, Komitetu Ministriv, Konhresu mistsevykh i rehionalnykh vlad Rady Yevropy [Proceedings of the Venice Commission, the Parliamentary Assembly, the Committee of Ministers, the Congress of Local and Regional Authorities of the Council of Europe]. Kyiv. [in Ukrainian].

32. Izbiratelnyy kodeks Turkmenistana, 2013 (s izmeneniyami i dopolneniyami po sostoyaniyu na 09.06.2020) [Electoral Code of Turkmenistan, 2013 (with amendments and additions as of 09.06.2020) (Mejlis of Turkmenistan)]. (Medzhlis Turkmenistana). Yurist [Lawyer] <https://online.zakon.kz/document/ ?doc_id=31386493\#pos=6;-106/> . (2020, June, 09). [in Russian]. 